\title{
Regulation of Experimental Peritonitis: A Complex Orchestration
}

\author{
L.-P. Laurin ${ }^{a, b} \quad$ M.-J. Brissette ${ }^{a} \quad$ S. Lepage ${ }^{a} \quad$ J.F. Cailhier ${ }^{a, b}$ \\ a Research Centre, Centre Hospitalier de I'Université de Montréal (CRCHUM) and Institut du Cancer de Montréal and \\ ${ }^{b}$ Renal Division, CHUM, Université de Montréal, Montréal, Qué., Canada
}

\section{Key Words}

Experimental peritonitis - Macrophages - Lymphocytes •

Mast cells $\cdot$ Leukocyte recruitment $\cdot$ Chemokines

\begin{abstract}
Experimental peritonitis is a frequently used inflammatory model to evaluate leukocyte recruitment. By the intrinsic characteristics of the peritoneal cavity, the various resident cell populations have a role to play in the initiation, the modulation and the resolution of peritoneal inflammation. Through various manipulations of these cell populations, we gained important knowledge on their respective roles in peritoneal inflammation. In this brief review, we will focus on the cellular regulation of leukocyte recruitment in experimental peritonitis.

Copyright $\odot 2012$ S. Karger AG, Basel
\end{abstract}

\section{Introduction}

The peritoneal cavity constitutes a protective barrier against damage and reduces friction between the intestines and surrounding tissues. The peritoneum is constituted of mesothelial cells $(\mathrm{MeC})$, resident leukocytes and fibroblasts which are situated between the $\mathrm{MeC}$ lining and the capillaries. All of these cells are important as they are metabolically active and act as a barrier to invading pathogens by generating an innate and adaptive immu- nological response upon determined leukocyte kinetics, as depicted in table 1 and figure 1 . The peritoneal serosal cavity is lined by a monolayer of $\mathrm{MeC}$, which constitute the most abundant cell type. The resident leukocytes are comprised mainly of macrophages $(M \Phi)$. In humans, the peritoneal resident leukocyte population is composed of 45-90\% MФ, 10-47\% lymphocytes [45\% T (mostly memory $\mathrm{T}$ cells) and $2 \%$ B lymphocytes], $8 \%$ natural killer (NK) cells, $2-6 \%$ dendritic cells (DC) and $<5 \%$ polymorphonuclear leukocytes (PMN) [1]. Here, we will review their respective roles in different rodents models of experimental peritoneal inflammation (table 2).

Table 1. Leukocyte kinetics during general peritoneal inflammation

\begin{tabular}{|c|c|c|c|c|}
\hline & Onset & $\begin{array}{l}\text { Pro- } \\
\text { gression }\end{array}$ & $\begin{array}{l}\text { Reso- } \\
\text { lution }\end{array}$ & $\begin{array}{l}\text { Postreso- } \\
\text { lution }\end{array}$ \\
\hline $\mathrm{PMN}$ & $\uparrow \uparrow$ & $\uparrow \uparrow \uparrow$ & $\downarrow$ & $\downarrow$ \\
\hline МФ & $\uparrow$ (inflammatory) & $\uparrow \uparrow$ & $\uparrow \uparrow \uparrow$ & $\downarrow$ \\
\hline B1 cells & $\downarrow$ & $\downarrow$ & $\uparrow$ & $\uparrow \uparrow$ \\
\hline T cells & $\uparrow$ & & & $\uparrow \uparrow$ \\
\hline NK & $\uparrow \uparrow$ & & & $\uparrow \uparrow$ \\
\hline MC & $\uparrow($ modulation $)$ & & & \\
\hline DC & $\uparrow$ & $\uparrow \uparrow$ & $\downarrow$ & \\
\hline $\mathrm{MeC}$ & $\mathrm{N} / \mathrm{A}$ & N/A & $\mathrm{N} / \mathrm{A}$ & N/A \\
\hline
\end{tabular}

The table reflects the views of the authors based on the available literature. N/A = Not applicable.

\section{KARGER \\ Fax +41613061234 \\ E-Mail karger@karger.ch}

www.karger.com
(ㄷ) 2012 S. Karger AG, Basel

$1660-2129 / 12 / 1201-0041 \$ 38.00 / 0$

Accessible online at:

www.karger.com/nee
J.F. Cailhier

Research Centre CHUM, Pavillon JA DeSeve, Y-4622

2099 Alexandre DeSeve Street

Montréal, QC H2L 4M1 (Canada)

E-Mail jf.cailhier@umontreal.ca 
Table 2. Experimental peritonitis models

\begin{tabular}{|c|c|c|c|c|c|}
\hline Stimuli & Peritonitis models & $\begin{array}{l}\text { PMN influx } \\
\text { (onset) }\end{array}$ & $\begin{array}{l}\text { PMN influx } \\
\text { (late) }\end{array}$ & Peritoneal chemokines & Peritoneal cytokines \\
\hline Zymosan & $\begin{array}{l}\text { Ajuebor et al. [18] } \\
\text { Kolaczkowska et al. [13] }\end{array}$ & $\begin{array}{l}\uparrow 4 \mathrm{~h} \\
\uparrow 6 \mathrm{~h}\end{array}$ & $\downarrow 24 \mathrm{~h}$; basal level $48 \mathrm{~h}$ & $\begin{array}{l}\text { MCP- } 1 \uparrow 2 \mathrm{~h} \text { and peak } 4 \mathrm{~h} ; \downarrow 24 \mathrm{~h} \\
\text { MCP- } 1 \text { and KC } \uparrow 6 \mathrm{~h}\end{array}$ & $\begin{array}{l}\text { IL- } 10 \uparrow 4 \mathrm{~h} \text {; basal level } 24 \mathrm{~h} \\
\mathrm{IL}-10 \text { and IFN- } \gamma \uparrow 6 \mathrm{~h}\end{array}$ \\
\hline LPS & Ajuebor et al. [18] & $\uparrow 16 \mathrm{~h}$ & $\downarrow 48 \mathrm{~h}$ & $\mathrm{MCP}-1 \uparrow 1 \mathrm{~h}$ and peak $3 \mathrm{~h} ; \downarrow 24 \mathrm{~h}$ & N/A \\
\hline Thioglycollate & $\begin{array}{l}\text { Ajuebor et al. [18] } \\
\text { Kipari et al. [14] } \\
\text { Cailhier et al. [21] }\end{array}$ & $\begin{array}{l}\uparrow 4 \mathrm{~h} \\
\uparrow 24 \mathrm{~h} \\
\uparrow 8 \mathrm{~h}\end{array}$ & $\begin{array}{l}\uparrow 48 \mathrm{~h} \\
\downarrow 72 \mathrm{~h} \\
\downarrow 72 \mathrm{~h}\end{array}$ & $\begin{array}{l}\mathrm{MCP}-1 \uparrow 4 \mathrm{~h} \\
\mathrm{MIP}-2 \text { and } \mathrm{KC} \uparrow 3 \mathrm{~h} \\
\mathrm{MCP}-1 \uparrow 6 \mathrm{~h} \\
\mathrm{MIP}-2 \text { and } \mathrm{KC} \uparrow 1 \mathrm{~h}\end{array}$ & N/A \\
\hline $\begin{array}{l}\text { Casein digest } \\
\text { Bacto-Tryptone }\end{array}$ & Knudsen et al. [19] & $\uparrow 24 \mathrm{~h}$ & N/A & MIP- $2 \uparrow 4 \mathrm{~h} ; \downarrow 6 \mathrm{~h}$ & $\mathrm{IL}-1 \beta \uparrow 2 \mathrm{~h} ; \downarrow 24 \mathrm{~h}$ \\
\hline $\begin{array}{l}\text { Bacteria } \\
\text { (E. faecium) }\end{array}$ & Leendertse et al. [20] & $\uparrow 6 \mathrm{~h}$ & $\downarrow 96 \mathrm{~h}$ & $\mathrm{MCP}-1 \uparrow 6 \mathrm{~h} ; \downarrow 24 \mathrm{~h}$ & $\begin{array}{l}\text { IL-6, IL-10 and TNF- } \alpha \uparrow 6 \mathrm{~h} ; \\
\downarrow 24 \mathrm{~h}\end{array}$ \\
\hline
\end{tabular}

$\mathrm{KC}=$ Keratinocyte chemoattractant; MIP = macrophage inflammatory protein; N/A = not applicable.

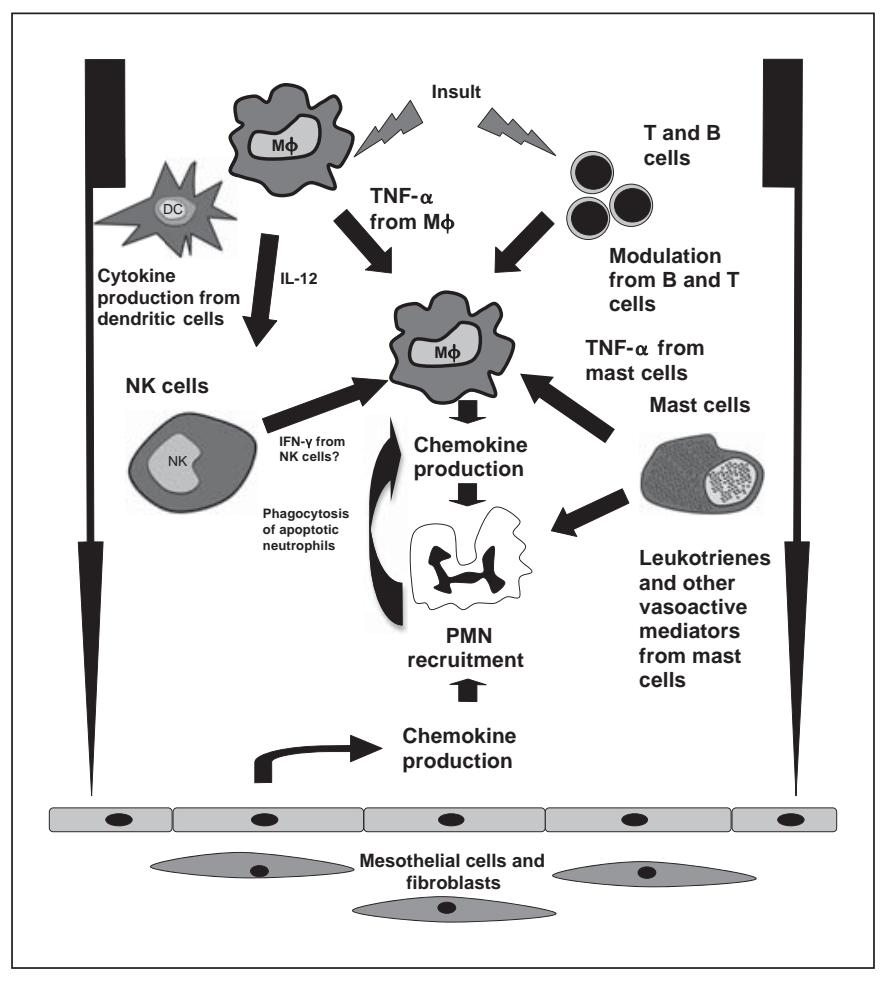

Fig. 1. Regulation of acute peritoneal inflammation. Upon an inflammatory insult, TNF- $\alpha$ would be secreted by resident $M \Phi$ and $\mathrm{MC}$, and IFN- $\gamma$ would be secreted by NK cells by a M $\Phi$-dependent IL-12 production. DC secrete various cytokines and chemokines contributing to the inflammatory and immune response. Resident $\mathrm{B}$ and $\mathrm{T}$ cells would affect this inflammatory response by an ill-defined mechanism and this would modulate chemokine production by $\mathrm{M} \Phi, \mathrm{MeC}$ and fibroblasts. This chemokine secretion and secretion of leukotrienes by MC would promote PMN recruitment.

\section{Implication in Human Peritonitis}

A better understanding of the interactions between the key players involved in the inflammatory response in peritonitis may be clinically relevant, particularly in peritoneal dialysis patients. Several peritoneal dialysis solutions, especially lactate-buffered non-glucose containing fluid, could impair leukocytes recruitment, as suggested in lipopolysaccharide (LPS)-induced peritonitis in rats [2]. As stated below, immune responses against offending organisms can adopt different profiles, depending on which kind of bacteria is implicated [3]. Drainage solution can also discard resident and recruited leukocytes, thereby modulating the inflammatory response. However, the exact clinical consequences on the evolution of peritonitis are unknown.

\section{Polymorphonuclear Leukocytes}

PMN are recruited to target tissues such as the peritoneal cavity by responding to a chemoattractant gradient generated by activated resident cells (e.g. $M \Phi)$ in response to a pathogenic agent (e.g. bacteria). PMN effector systems are activated following phagocytosis of a pathogen. The PMN oxidative response is characterized by the production of oxygen radicals, chemokines and the release of preformed proteins stored in granules (serine proteases, metalloproteinases, etc.). PMN apoptosis via proteolytic cascades (e.g. caspase-3 activation) and subsequent engulfment by $M \Phi$ is thought to be the major mechanism 
Table 3. Peritonitis in lymphocyte-deficient mice (adapted from Kipari et al. [14])

\begin{tabular}{|c|c|c|c|c|c|c|}
\hline & $\begin{array}{l}\text { Baseline resident } \\
\text { peritoneal cells }\end{array}$ & $\begin{array}{l}\text { Circulating } \\
\text { number of } \\
\text { PMN }\end{array}$ & $\begin{array}{l}\text { Peritoneal } \\
\text { PMN } \\
\text { infiltration }\end{array}$ & $\begin{array}{l}\text { Circulating } \\
\text { number of } \\
\text { monocytes }\end{array}$ & $\begin{array}{l}\text { Peritoneal } \\
\text { monocytes/ } \\
\text { MФ infiltration }\end{array}$ & $\begin{array}{l}\text { Peritoneal } \\
\text { chemokines (KC, } \\
\text { MIP-2 and MCP-1) }\end{array}$ \\
\hline $\begin{array}{l}\text { RAG KO } \\
\text { (absence of T and B cells) }\end{array}$ & $\begin{array}{l}\uparrow \mathrm{M} \Phi \\
\downarrow \mathrm{MC}\end{array}$ & no difference & $\uparrow(8$ and $24 \mathrm{~h})$ & $\downarrow$ & $\begin{array}{l}\text { early } \uparrow(8 \mathrm{~h}, 24 \mathrm{~h}) \\
\text { late } \downarrow(72 \mathrm{~h})\end{array}$ & $\downarrow \mathrm{MCP}-1(24 \mathrm{~h})$ \\
\hline $\begin{array}{l}\text { NUDE mice } \\
\text { (absence of T cells) }\end{array}$ & $\begin{array}{l}\text { no difference }-M \Phi \\
\downarrow \mathrm{MC} \\
\downarrow \mathrm{B} \text { cells }\end{array}$ & no difference & $\uparrow(8$ and $24 \mathrm{~h})$ & no difference & early $\uparrow(24 \mathrm{~h})$ & $\begin{array}{l}\uparrow \mathrm{KC}(8 \mathrm{~h}) \\
\uparrow \mathrm{MCP}-1(3 \mathrm{~h})\end{array}$ \\
\hline $\begin{array}{l}\mu \mathrm{MT} \text { mice } \\
\text { (absence of B cells) }\end{array}$ & $\begin{array}{l}\text { no difference - МФ } \\
\text { no difference - MC }\end{array}$ & $\downarrow$ & $\downarrow(24 \mathrm{~h})$ & no difference & late $\downarrow(72$ and $120 \mathrm{~h})$ & no difference \\
\hline
\end{tabular}

$\mathrm{KC}=$ Keratinocyte chemoattractant; $\mathrm{MIP}=$ macrophage inflammatory protein; N/A = not applicable.

for clearing PMN during the resolution phase. $M \Phi$ can trigger PMN apoptosis by Fas-Fas ligand pathway that represents a negative feedback loop accelerating the resolution of inflammation whilst phagocytosis of senescent $\mathrm{PMN}$ inhibits the inflammatory mediators production by $\mathrm{M} \Phi[4]$.

\section{Lymphocytes}

\section{B Lymphocytes}

Peritoneal B lymphocytes are divided into 4 different subpopulations according to their expression of CD5 (Ly-1) and MAC-1. B-1 cells express a B220 low $/ \mathrm{CD}^{+} /$ MAC- $1^{\text {low }}$ phenotype. The B-1 cells represent approximately $50 \%$ of the $\mathrm{B}$ cell population in the murine peritoneum (10-20\% of total peritoneal cells are B-1 cells) and are the most relevant subtype implicated in peritoneal inflammation [5]. B-1 cells constitute another arm of the innate immune system. One of their specific functions is the synthesis of natural antibodies (IgM). Furthermore, they are key players in the modulation of the response to surperinfection in murine peritonitis [6] and in the recruitment of monocytes and $M \Phi$ without T cell help.

\section{T Lymphocytes}

The majority of peritoneal T cells express the $\alpha \beta$ T cell receptor (TcR) with around $17 \%$ expressing the $\gamma \delta$ TcR. The CD4/CD8 ratio also differs from that evident in the blood where most of the T cells are CD8+. Although the majority of peritoneal CD8+ cells secrete a Th1 pattern of cytokines such interleukin (IL)-2 as well as the cytotoxic mediators interferon (IFN) $-\gamma$ and tumor necrosis factor (TFN)- $\alpha$, some peritoneal CD8+ cells secrete IL- 4 and
IL-5 that are characteristic of Th2 cells [7]. These Th2type cells are able to support B cell differentiation and secretion of IgG and IgA [7], whilst $\gamma \delta$ T cells would play an important role in monocyte/M $\Phi$ differentiation [8].

\section{Resident Natural Killer T Cells and Natural Killer Cells}

The NK T cell population is enriched in the human peritoneal cavity of healthy continuous ambulatory peritoneal dialysis (CAPD) patients; $20 \%$ of the peritoneal lymphocytes are NK T cells, whilst $4.2 \%$ are CD8+ NK cells [9]. Activated peritoneal NK cells produce a spectrum of cytokines such as TNF- $\alpha$, IFN- $\gamma$, GM-CSF, lymphotoxin and IL-8 [10], whereas NK T cells can produce Th1-type cytokines (such as IFN- $\gamma$ and TNF- $\alpha$ ) as well as Th2-type cytokines (such as IL-4 and IL-13) [11]. The production of IFN- $\gamma$ by NK T cells is induced by M $\Phi$-dependent IL-12 production. NK T cells can mediate cytotoxicity through Fas-Fas ligand and perforin/granzyme pathways. It remains to be determined if $\mathrm{NK} \mathrm{T}$ cells are regulators or effectors of immune-mediated damage. Although the role of NK T cells in peritonitis remains ill defined, it is likely that the modulation of the inflammatory response via IFN- $\gamma$ secretion and the subsequent effects upon cytokine and chemokine production might be of some importance [12].

\section{Lymphocyte-Deficient Mice as a Model for Studying}

Lymphocyte Function in Experimental Peritonitis

Different mice models to study lymphocyte functions are available, as stated in table 3. A naturally occurring mutation in NUDE mice resulted in congenital absence of the thymus resulting in absence of T cell development. The $\mu \mathrm{MT}$ KO mice were generated by disruption of one 
of the exons coding for the $\mu$-chain with the consequential arrest of B cell development at the stage of pre-B-cell maturation, resulting in an absence of mature $B$ cells. RAG-1 KO lack mature T and B cells but other immune mediators are increased such as complement activity and NK cell activity.

There are scant data available regarding the function of lymphocytes during the initiation of acute peritoneal inflammation. Recent work by Kolaczkowska et al. [13] demonstrated comparable changes between RAG-deficient mice and wild-type mice in vascular permeability and PMN infiltration in the model of zymosan peritonitis. In contrast, work by Rajakaria et al. [6] suggested that RAG-deficient mice exhibited an exaggerated peritoneal response to zymosan with increased PMN infiltration accompanied by increased TNF- $\alpha$ and reduced IL-10 levels. Recent data highlighted the role of lymphocytes in the modulation of PMN and monocyte/M $\Phi$ recruitment in Brewer's thioglycollate (BTG) peritonitis. T cells would act to limit leukocyte recruitment with an absence of $\mathrm{T}$ cells facilitating increased $\mathrm{PMN}$ and monocyte/M $\Phi$ recruitment. B cells would play a role in promoting $M \Phi$ recruitment in the later phase of inflammation as both RAG-1 KO mice and $\mu$ MT mice exhibited reduced monocyte/macrophage $(\mathrm{M} \Phi)$ recruitment at late time points [14].

\section{Macrophages}

$M \Phi$ are heterogeneous cells and can be found in tissues where they are known as resident $M \Phi$. The local microenvironment will provide tissue-specific signals such as apocrine secretion products from neighboring resident cells and extracellular matrix. These local mediators play a prominent role in the development of the different phenotypes found in the various resident $M \Phi$ populations. Resident $M \Phi$ have an important role in the immune protection of their respective organ of residence and resident tissue $M \Phi$ are regarded as sentinels of the in nate immune system. They are implicated in the clearance of pathogens and the repair of injured tissue.

It has been suggested that there are two distinct monocyte populations that give rise to either resident $M \Phi$ or inflammatory $\mathrm{M} \Phi$ and that these monocytes may be distinguished by their surface markers. Intraperitoneal migration of resident $M \Phi$-precursor monocytes is not prominent in the absence of inflammation. During inflammatory peritonitis; however, there is some recruitment of the long-lived $\mathrm{CX}_{3} \mathrm{CR} 1^{\mathrm{Hi}}, \mathrm{Gr}^{-}$and $\mathrm{CCR} 2^{-}$mono- cytes [15] and this may be to replace the resident $M \Phi$ that emigrate to the parathymic lymph nodes during and following inflammation.

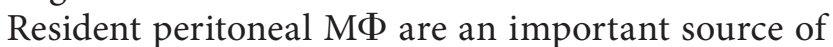
cytokines and chemokines involved in the immune defense of the peritoneal cavity. It is believed that this 'cytokine network' facilitates communication between peritoneal $\mathrm{M} \Phi$ and $\mathrm{MeC}$ that act in concert to protect the peritoneum [16]. Key players include the cytokines IL-1, IL- 6 and TNF- $\alpha$ and the chemoattractants IL-8, monocyte chemoattractant protein (MCP)-1, prostaglandins and leukotrienes. Furthermore, in recent years, new lipid mediators with anti-inflammatory properties have been discovered (e.g. resolvins and protectins), as opposed to the classic pro-inflammatory prostaglandins and leukotrienes. A new bioactive product named maresin-1 (MaR1), derived from docosahexaenoic, may also be involved in inflammation resolution. MaR1 would stop PMN infiltration and enhance nonphlogistic $M \Phi$ phagocytosis in the setting of mouse peritonitis [17].

In contrast, the role of resident peritoneal $M \Phi$ in the initiation of inflammation and orchestration of PMN recruitment is more controversial. It is of interest that previous work using clodronate to study the role of resident peritoneal $M \Phi$ in the initiation of experimental peritonitis has produced conflicting results [18, 19]. Ajuebor et al. [18] showed that $M \Phi$ ablation had no effect upon PMN recruitment in the BTG and zymosan model of peritonitis. In contrast, Knudsen et al. [19] demonstrated that $M \Phi$ blunted PMN influx in their casein model of peritonitis. More recently, Leendertse et al. [20] demonstrated that depletion of resident peritoneal $M \Phi$ delayed the peritoneal clearance of Enterococcus faecium with increased production of inflammatory cytokines and chemokines associated with systemic dissemination. A murine transgenic conditional $M \Phi$ ablation model also showed that absence of MФ attenuated PMN infiltration with diminished C-X-C chemokine production at $1 \mathrm{~h}$ [21].

\section{Dendritic Cells}

DC represent $1 \%$ of the resting resident peritoneal cells in rats [22]. They play a key role in the interactions with the adaptive arm of the immune response, i.e. $\mathrm{T}$ and $\mathrm{B}$ lymphocytes. Similarly to $M \Phi$, resident DC exhibit different phenotypes and share numerous $M \Phi$ markers and functions that highlight the close relationship between $\mathrm{M} \Phi$ and DC. A subset of DC, named regulatory DC, pro- 
duced fewer pro-inflammatory cytokines and instead preferentially produced IL-10. This, not only suppressed bacterial LPS-induced production of pro-inflammatory cytokines in $M \Phi$, but also reduced their serum levels in mice [23].

The sensing function of DC, as for $M \Phi$, is mediated through various innate immune receptors such as the Toll-like receptors. These receptors can react to different classes of infectious agents including bacteria and viruses. Upon receptor ligation, DC can up-regulate genes leading to expression of various cytokines and chemokines involved in the inflammatory and immune response such as IL-1 $\beta$, IL-1 receptor antagonist, TNF- $\alpha$, IL-2, IL-6, IL-12 p40, MIP-1 $\alpha,-1 \beta,-1 \gamma$, MIP- $2 \alpha$, MCP-5, macrophage migration inhibitory factor, inducible protein-10 and GRO-1 [24].

In humans, myeloid DC precursors $\left(\mathrm{CD} 14^{+} \mathrm{CD} 4^{+}\right)$represent $2.2 \%$ of peritoneal cells at basal state in a recent study on peritoneal dialysis (PD) patients [3]. This number contrasts with older studies that have concluded that the population of DC represents $6 \%$ of total peritoneal cells. Peritoneal $\mathrm{CD} 14^{+} \mathrm{CD} 4^{+}$numbers increased significantly in PD-associated peritonitis patients, and seemed to occur with different pattern for Gram-positive and Gram-negative bacterial infection, reflecting a potential role in the peritoneal adaptive immune responses.

\section{Resident Mast Cells}

There are two classes of mast cells (MC) in the mouse: connective tissue MC and mucosal MC. As is the case for resident $M \Phi, M C$ complete their maturation in the tissue of residence under the influence of the local microenvironment. MC exist only as 'resident' cells and can produce inflammatory mediators such as histamine, platelet-activating factor, prostaglandins, thromboxane, leukotriene, chymase, cytokines (GM-CSF, TNF- $\alpha$, IL-1, IL-3, IL-4 and IL-6) and chemokines (MCP-1 and MIP$1 \alpha$ ) [25]. The production of leukotrienes by $\mathrm{MC}$ is an important facet of the early PMN recruitment in a model of infectious peritonitis [26]. MC depletion had no effect upon BTG induced peritonitis, reduced PMN infiltration in LPS-induced peritonitis (though no chemokine differences were evident) and inhibited PMN influx and chemokine secretion in zymosan-induced peritonitis [18]. In summary, MC play a role in the initiation of inflammation, but many studies indicate that the main contribution of $\mathrm{MC}$ is in the modulation of the inflammatory response.

Regulation of Experimental Peritonitis

\section{Mesothelial and Stromal Cells}

The $\mathrm{MeC}$ lining constitutes a protective barrier to physical and infectious injury and has complex role in the immunity of the serosal cavity. In vivo and in vitro studies have demonstrated that peritoneal $\mathrm{MeC}$ produce proinflammatory cytokines such as IL-1 $\beta$, TNF- $\alpha$ and IL- 6 , anti-inflammatory molecules such as IL-10 and the decoy molecule IL-1 receptor type II (IL-1RII) and prostaglandins. Stimulated $\mathrm{MeC}$ increased their expression of adhesion molecules and produced chemokines (IL-8, MCP-1 and regulated upon activation, normal $\mathrm{T}$ expressed and secreted; RANTES), which represent essential steps in order to mount an inflammatory response [27]. Fibroblasts are present in the interstitial stroma beneath the $\mathrm{MeC}$ layer and are also implicated in serosal inflammation.

$\mathrm{MeC}$ involvement in the initiation of inflammation is unquestionable whilst the underlying population of fibroblasts may also be involved. However, most studies involved the study of chemokine and cytokine production after the activation of $\mathrm{MeC}$ and this raised the possibility that other cells may well be involved in the initial production of these activating cytokines. A 'cytokine network' between the resident cells is therefore essential for the initiation of inflammation. Some studies have suggested that resident $\mathrm{M} \Phi$-derived pro-inflammatory cytokines such as TNF- $\alpha$ would be essential for the secretion of C-X-C and C-C chemokines from $\mathrm{MeC}$ and fibroblasts [27].

\section{Conclusions}

Experimental peritonitis is a good model to understand the complex orchestration between key players involved in initiation and regulation of inflammation. M $\Phi$ seem to play a central role in the cytokine network with mesothelial and stromal cells. Other resident leukocytes act more as modulators of the inflammatory response, as depicted in figure 1 .

\section{Acknowledgments}

This work was supported by a Biomedical Research Grant from the Kidney Foundation of Canada, from le Fonds de la recherche en santé du Québec, la Fondation du CHUM and the Institut du Cancer de Montréal. J.F.C. is recipient of a Fonds de la recherche en santé du Québec clinician-scientist scholarship. We thank the J.L. Lévesque Foundation and the CHUM renal division for their support.

Nephron Exp Nephrol 2012;120:e41-e46 e45 


\section{References}

$>$ Kubicka U, Olszewski WL, Tarnowski W, Bielecki K, Ziolkowska A, Wierzbicki Z: Normal human immune peritoneal cells: subpopulations and functional characteristics. Scand J Immunol 1996;44:157-163.

$\checkmark 2$ Mortier S, Faict D, Gericke M, Lameire N, De Vriese A: Effects of new peritoneal dialysis solutions on leukocyte recruitment in the rat peritoneal membrane. Nephron Exp Nephrol 2005;101:e139-e145.

\3 McCully ML, Chau TA, Luke P, Blake PG, Madrenas J: Characterization of human peritoneal dendritic cell precursors and their involvement in peritonitis. Clin Exp Immunol 2005;139:513-525.

4 Witko-Sarsat V, Rieu P, Descamps-Latscha B, Lesavre P, Halbwachs-Mecarelli L: Neutrophils: molecules, functions and pathophysiological aspects. Lab Invest 2000;80: 617-653.

$\checkmark 5$ Hayakawa K, Hardy RR, Herzenberg LA: Progenitors for ly-1 b cells are distinct from progenitors for other B cells. J Exp Med 1985; 161:1554-1568.

6 Rajakariar R, Lawrence T, Bystrom J, Hilliard M, Colville-Nash P, Bellingan G, Fitzgerald D, Yaqoob MM, Gilroy DW: Novel biphasic role for lymphocytes revealed during resolving inflammation. Blood 2008;111 4184-4192.

>7 Birkhofer A, Rehbock J, Fricke H: T lymphocytes from the normal human peritoneum contain high frequencies of Th2-type CD8+ T cells. Eur J Immunol 1996;26:957-960.

$>8$ Skeen MJ, Freeman MM, Ziegler HK: Changes in peritoneal myeloid populations and their proinflammatory cytokine expression during infection with Listeria monocytogenes are altered in the absence of gamma/ delta t cells. J Leukoc Biol 2004;76:104-115.
9 Lewis SL, Kutvirt SG, Cooper CL, Bonner PN, Holmes CJ: Characteristics of peripheral and peritoneal lymphocytes from continuous ambulatory peritoneal dialysis patients. Perit Dial Int 1993;13(suppl 2):S273-S277.

10 Das S, Khar A: Regulation of NK cell function in vivo by the dose of tumour transplanted in the peritoneum. Immunol Lett 2002;83:133-142.

11 Smyth MJ, Godfrey DI: Nkt cells and tumor immunity - a double-edged sword. Nat Immunol 2000;1:459-460.

12 Godfrey DI, Kronenberg M: Going both ways: immune regulation via CD1d-dependent NKT cells. J Clin Invest 2004;114:1379_ 1388.

13 Kolaczkowska E, Barteczko M, Plytycz B, Arnold B: Role of lymphocytes in the course of murine zymosan-induced peritonitis. Inflamm Res 2008;57:272-278.

14 Kipari T, Watson S, Houlberg K, Lepage S, Hughes J, Cailhier JF: Lymphocytes modulate peritoneal leukocyte recruitment in peritonitis. Inflamm Res 2009;58:553-560.

15 Geissmann F, Jung S, Littman DR: Blood monocytes consist of two principal subsets with distinct migratory properties. Immunity 2003;19:71-82.

16 Topley N, Mackenzie RK, Williams JD: Macrophages and mesothelial cells in bacterial peritonitis. Immunobiology 1996;195:563573.

17 Serhan CN, Yang R, Martinod K, Kasuga K, Pillai PS, Porter TF, Oh SF, Spite M: Maresins: novel macrophage mediators with potent antiinflammatory and proresolving actions. J Exp Med 2009;206:15-23.

$>18$ Ajuebor MN, Das AM, Virag L, Flower RJ, Szabo C, Perretti M: Role of resident peritoneal macrophages and mast cells in chemokine production and neutrophil migration in acute inflammation: evidence for an inhibitory loop involving endogenous il-10. J Immunol 1999;162:1685-1691.
19 Knudsen E, Iversen PO, Van Rooijen N, Benestad HB: Macrophage-dependent regulation of neutrophil mobilization and chemotaxis during development of sterile peritonitis in the rat. Eur J Haematol 2002;69:284-296.

20 Leendertse M, Willems RJ, Giebelen IA, Roelofs JJ, van Rooijen N, Bonten MJ, van der Poll T: Peritoneal macrophages are important for the early containment of Enterococcus faecium peritonitis in mice. Innate Immun 2009;15:3-12.

21 Cailhier JF, Partolina M, Vuthoori S, Wu S, Ko K, Watson S, Savill J, Hughes J, Lang RA: Conditional macrophage ablation demonstrates that resident macrophages initiate acute peritoneal inflammation. J Immunol 2005;174:2336-2342.

22 van Vugt E, Arkema JM, Verdaasdonk MA, Beelen RH, Kamperdijk EW: Morphological and functional characteristics of rat steady state peritoneal dendritic cells. Immunobiology 1991;184:14-24.

$>23$ Fujita S, Seino K, Sato K, Sato Y, Eizumi K, Yamashita N, Taniguchi M: Regulatory dendritic cells act as regulators of acute lethal systemic inflammatory response. Blood 2006;107:3656-3664

-24 Granucci F, Vizzardelli C, Pavelka N, Feau S, Persico M, Virzi E, Rescigno M, Moro G, Ricciardi-Castagnoli P: Inducible il-2 production by dendritic cells revealed by global gene expression analysis. Nat Immunol 2001;2: 882-888.

25 Metcalfe DD, Baram D, Mekori YA: Mast cells. Physiol Rev 1997;77:1033-1079.

26 Malaviya R, Abraham SN: Role of mast cell leukotrienes in neutrophil recruitment and bacterial clearance in infectious peritonitis. J Leukoc Biol 2000;67:841-846.

27 Broche F, Tellado JM: Defense mechanisms of the peritoneal cavity. Curr Opin Crit Care 2001;7:105-116. 